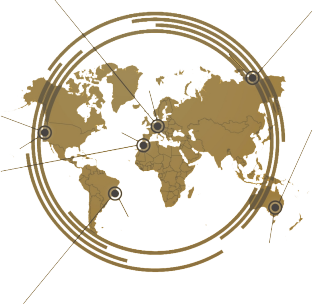

\title{
Learning from home during
} pandemic: A blended learning for reading to write activity in EFL setting

\author{
Lestari Setyowati $^{1 *}$, Sony Sukmawan ${ }^{2}$, Ana Aksana El-Sulukkiyah ${ }^{1}$ \\ ${ }^{1}$ Universitas PGRI Wiranegara, ${ }^{2}$ Universitas Brawijaya Malang
}

The pandemic of COVID 19 has forced teachers all around the world to be adaptable to the situation. Within the foreign language (FL) context, the teaching of language skills provides challenges for teachers in terms of how to deliver the materials as effectively and as efficiently as possible. The study aims to describe the steps of reading to write activity for essay writing in FL settings and what the students feel about it. The design of the study is a case study design. The subjects of the study were the fourth-semester students of English Education Study Program. The result of the study shows that there are three main steps of teaching scenarios. They are the pre-activity, whilst activity, and post-activity, with some specifications depending on the skills. The reading section employs the silent reading activity, skimming, and scanning technique through telegram application. The writing section implements the process approach, namely planning, drafting, revising, and publishing. The technologies used were Telegram, WhatsApp, Google Meet, YouTube, Grammarly, and Plagiarism Checker online application. The result shows that, although the students feel reluctant and uneasy at the beginning with the blended learning, they get used to it and confess that they have a lot to learn, not only in terms of the course materials but also the digital technology skills improvement. Despite the credit quota and signal problems, they feel positive with the way of new learning.

Keywords: blended learning, pandemic, reading, writing

\section{INTRODUCTION}

OPEN ACCESS

ISSN 25033492 (online)

*Correspondence: Lestari Setyowati lestari.setyowati@yahoo.co.id

Received: 15 th July 2020 Accepted: 22nd November 2020

Published: 17th January 2021

Citation:

Setyowati L, Sukmawan S and El-Sulukkiyah AA (2021) Learning from home during pandemic: A blended learning for reading to write activity in EFL setting.

J. Eng. Educ. Society. 6:1. doi: 10.21070/jees.v6i1.662
With the outbreak of COVID 19 in the world, teachers/lecturers often wonder whether they would teach the same way again, or they would teach differently. Changing the way of teaching is undoubtedly the only option for teachers/lecturers. The pandemic of COVID 19 has forced them to spend most of the time at home, to work, to learn, yet at the same time, to stay productive. The uncertainty of when the pandemic will end has forced teachers around the world to make the most use of digital technology to teach and accomplish the learning objectives.

This is the point where the integrated/mixed learning model (blended learning) becomes the apple of the eye of everyone's favor in the educational setting because it reaches far and beyond. Yet, many teachers/lecturers are not aware that before the pandemic, the blended learning instruction has come into the classroom in a smaller portion. Blended learning is also sometimes referred to as the hybrid course Allen et al. (2007); Graham (2006) which means mixed learning. There is no standard term to define blended learning. However, Graham (2006) defines blended learning as follows, "systems combine face -to-face instruction with computermediated instruction". Thus, blended learning is the merging of two very different learning 
models, namely the traditional face-to-face model, and modern technology-based learning model. Therefore, broadly speaking, blended learning can be interpreted as a learning method that combines conventional face-to-face learning and electronic / internet-based learning Allen et al. (2007); Idris (2018) With the rapid development of technology today, Graham (2006) estimates that in the future, the use of digital technology in learning will be increasingly inseparable. Furthermore, he explained three reasons why blended learning was popular in the community. The first is because this model improves the quality of learning, the second is because of its easy access and high flexibility, and the third is because it is economical in terms of financing.

The learning model of blended learning has been going on for a long time, especially since the development of information technology systems Idris (2018). This makes all learning resources accessible online / offline. The blended learning model allows teachers and students to do distance learning through video conferencing so that distance, space and time are no longer a problem. Fully online and integrated learning (that is, which combines elements of an online class and face-toface) has grown very rapidly in Western society for a long time. Educational providers there believe that integrated learning is as promising as online learning Allen et al. (2007). Technically, face-to-face learning can be carried out online and offline. Offline face-to-face learning is conventional face-to-face learning that is usually done in the classroom. While online face-toface learning is the one that can be carried out remotely online using available applications, such as zoom and Google Meet.

Every educational institution suffers from the COVID 19 outbreaks. The pandemic forced the teaching and learning system in the institution to be adaptable to the situation. At the beginning of the semester, the teaching and learning process was done in a face to face interaction. However, three months later, the Indonesian government issued a policy of stay home, a study from home, and work from home order. As the learning must continue, the institution distributed a policy that all teaching and learning process must be conducted online until the end of the semester. The teaching and learning which was conducted in a conventional face to face interaction, in the beginning, was combined and blended with online learning. This paper aims to describe the implementation of blended learning during the COVID 19 pandemic in the teaching of the essay writing class. Specifically, this paper discusses the steps of reading to write activity in writing a process essay and to describe the students' feelings during the implementation of a blended learning model.

\section{Blended Learning}

The rapid development of digital technology has influenced the world of education and teaching innovation. Currently, teaching-learning innovation has unwittingly refocused on how educators deliver the material and how students learn at school Tandoh et al. (2013). The most common approach in integrated education involves face-to-face learning with webbased learning Tandoh et al. (2013). However, some people often wonder about the difference between hybrid-learning, elearning, and web-facilitated learning. Allen et al. (2007) mention that the terms blended-learning and hybrid-learning are two terms that refer to the same thing. In the research, Allen distinguished the term based on the table below.

Although it is not clear how Allen et al. (2007) define each estimate percentage, Table 1 gives better guidelines on how web-based learning is differentiated. Table 1 explains that learning is referred to as online learning if 80 percent of the learning content is delivered online and carried out without face to face at all. While the term integrated learning or blended learning applies to learning that has 30-70 percentage of being done online, with the rest is conducted conventionally. Graham (2006) estimates that in the future, learning with blended learning methods will be increasingly in demand. This is due to the rapid development of digital technology that affects the way humans communicate.

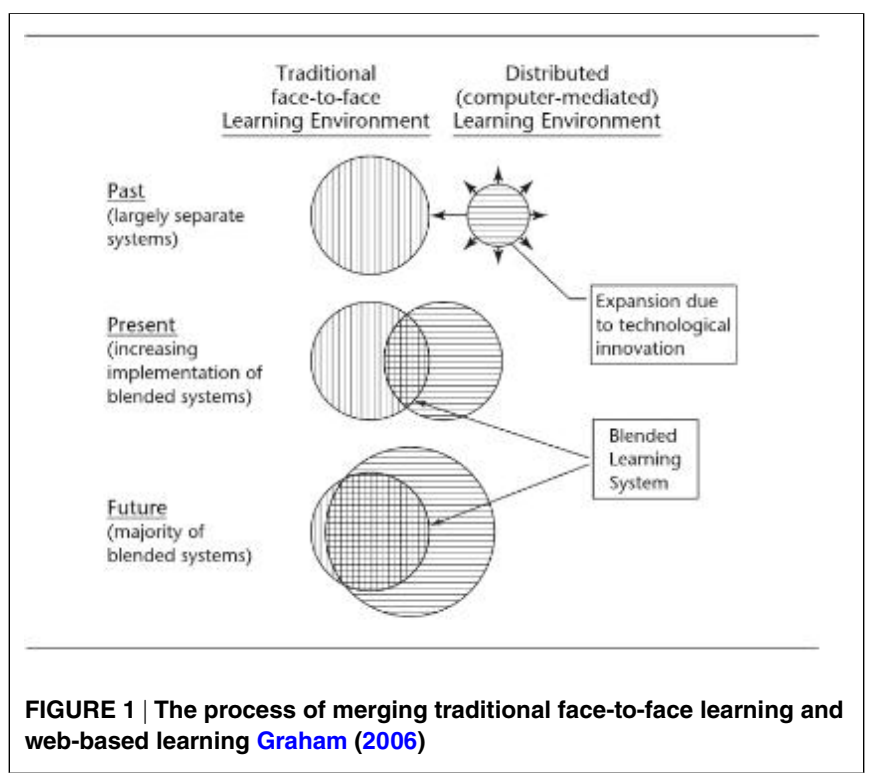

Figure 1 explains that in the past, learning only uses faceto-face instruction in the classroom. And, nowadays, digital technology has begun to influence learning instruction. In the future, Graham (2006) predicts that the learning process will utilize more digital technology with a blended learning method, which results in a fewer conventional face-to -face methods in the process. However, he confesses that the combination of these two methods will give a better outcome as they complement each other.

Osguthorpe and Graham (2003) mentions six reasons why blended learning is increasingly popular in education. The reasons are 1) it has pedagogical richness; 2) it gives broad access to knowledge; 3) it is easy for social interaction online; 4) it has personal agency, 5) it provides many benefits but with minimal cost (cost-effectiveness), and 5) it is easy to revise if there are errors (ease of revision). Furthermore, Graham (2006) also 
TABLE 1 | Web-Based Teaching Model Allen et al. (2007)

$\begin{array}{ll}\text { Web-based teaching percentage } & \text { Model } \\ 0 \% & \text { Traditional }\end{array}$

$-29 \%$

$0-79 \%$

Blended/hybrid

\section{Description}

1. Learning without using online facilities

2. Conventional face-to-face learning

1. The utilization of the Web in the learning process is to help improve the mastery of material that is not met in the face-to-face process (providing additional material through web-based technology)

2. It is utilized more for tasks submission

1. The learning process uses a combination of Web-based technology and face-to-face instruction

2. The portion of online learning is greater than face to face

3. In the learning process, the interaction (discussion forums) is mostly done online
$0-100 \%$
Online/

e-learning
1. All learning are through online

2. There is no face-to-face learning revealed three main reasons why blended learning is beneficial. The reasons are 1) to improve the quality of learning; 2) to provide easy access to education regardless of distance, time and space, flexible in its implementation (increased access and flexibility); and 3) to enable to reach a broad and large audience in a short time, yet, it is economical (cost-effectiveness).

The use of blended learning is not something new in the educational context. Literature studies reveal that blended learning is widely used not only for learning receptive language skills (reading, listening) and productive (speaking and writing), but also for teaching language components, such as grammar and spelling. Mabuan and Ebron (2017) explored the use of e-mail for teaching writing with a blended learning approach in the context of English as a second language, in Manila. The results of his research show that e-mail is very useful in helping improve the students' ability to write English. The result also shows that the use of emails gives the students the opportunity to collaborate and interact with peers, increase positive attitudes and confidence in writing English, as well as increase learning independence.

Furthermore, Mccall (2017) investigates the use of Facebook, to improve students' ability to read and write through classroom action research designs. In his research, the teacher created a micro blog on Facebook and held classes online with all his students. The teacher posts pictures and reading material for students, to read, comment on, and write summaries. Students wrote a summary of the micro blog in the classroom by using a laptop or other smart phone and allowed to complete the micro blog assignment at home if they have not been able to complete it in class. The results of his research show that the use of the Facebook application can improve the students' ability to write, especially in terms of sentence complexity. To get maximum results, scaffolding was given to the students. The results of research also show that the students give positive responses to the use of Facebook for learning to read and write.

Rahman and M (2018) investigates the effectiveness of the implementation of blended learning and compares it with conventional face-to-face methods. In the experimental class, the students use the blended learning method. The students receive feedback from peers and teachers through social media, complete assignments outside the classroom, and submit them through an application. Meanwhile, the control class uses conventional face-to-face methods. The students do not get mutual interaction, between peers and from the teacher. Learning in the classroom also does not vary, because all are centered on the teacher. The results of his study showed that students who learned by using blended learning methods had better writing performance than students in the control group. In addition, this study also revealed that $88 \%$ of students in the experimental class had the basic ability to operate computers independently and $76 \%$ of them have better internet skills. This is all because these students must participate in e-forum discussions, e-mails, and the use of other websites.

Similarly, in Indonesia, the use of Blended Learning is not something new either. Purnawarman et al. (2016) conducted a case study research for teaching writing with Edmodo and 
Genre-Based Approach through the Blended Learning model for grade 11 high school students in Cimahi, West Java. The use of Edmodo in the blended learning setting makes learning is more interactive and makes writing activities more meaningful.

Blended learning has also been applied in Islamic boarding schools in Indonesia, especially in Probolinggo, East Java. Through a qualitative approach, Hayati and Wijaya (2018) investigates how blended learning was implemented to improve the students' receptive skills in the Islamic boarding school. The results of their research revealed that there were 6 steps taken by the Islamic Boarding school to implement the blended learning method. Specifically, the stages of implementing Blended learning as a quote from Hayati and Wijaya (2018) are as follows. First, determining instructional materials. This step is in the form of (a) how the teaching material will be presented, (b) which teaching material is compulsory and which is recommended, (c) how the students can access the material, (d) what supporting factors are needed (software, group/ individual work). The next step is (2) determining the blended learning model that will be used. This relates to when the face-to-face meeting is held, for example at the beginning of the meeting only, or at the end of the meeting only, or just in the middle of the meeting, or determining how many times the classes will be held in face to face, and its frequency. As there is no standard conducting a blended learning format, each teacher can choose their own format that is unique and different from other teachers. The third step (3) determines how the online learning format will be implemented. For example, determining what applications/hosting will be used for online learning, such as Google, Yahoo, Telegram, etc.

The fourth step is determining the evaluation of the blended learning design. The teacher evaluates the implementation of online learning and asks students for input whether the application/host being used is functioning properly, or whether they have problems with signal or bandwidth. This evaluation needs to be done to find out whether online learning eases students and not causing problems. The next step (5) is the implementation of blended learning properly. In this step, the teacher informs the learning objectives, and the material that will be used, as well as how and where to download the material online. And the last step is (6) preparing the evaluation criteria for the implementation of blended learning. The teacher prepares assessment criteria to see whether the learning system is effective ( the content delivery, the format, interest, easiness, and cost-financing).

The research questions are described as follows.

1. How was the implementation of blended learning model for teaching Process Essay during the pandemic of COVID 19?

2. What are the students' perceptions during the implementation of blended-learning model during the pandemic of COVID 19?

\section{METHODS}

This study uses a qualitative approach focusing on case study design. The design is considered appropriate because the main goal of this research is to explore and describe the existing phenomenon of a particular subject in relation to the teaching of literacy skills during the pandemic of COVID 19. Creswell (2012) states that the 'case' can be a program, events, or activities which has a uniqueness in its implementation. The subjects of the study were the fourth-semester students of English Education Study Program in the academic year 2019-2020, Faculty of Pedagogy and Psychology, Universitas PGRI Wiranegara, East Java, Indonesia. To collect the data, the researchers used interviews, and documentation of personal chats, students' essays, lecturer's teaching reports, and a list of essays published in the YouTube platform. The data was collected in three months from April to June 2020. The researchers analyzed the data qualitatively since most of them were in the form of words, phrases, and sentences or non-numerical data.

The researchers also used data codification to separate the data based on the intended category, namely the draft, the revision, the chats. The students' writing was coded by using their name initials, batch, group, and part of sub-analysis. The process of data analysis follows Miles and Huberman (1994) model, namely data collection, data display, data reduction, and conclusion drawing. After the data were collected, they were displayed in the form of narratives, dialogues, chats, excerpts of the students' writing, and observation of students' You Tube videos. Only the data which were relevant to the purposes of the study were taken, and the irrelevant ones were omitted. The selected data were categorized and coded based on its classification. Each of these steps was done in a cyclic process.

\section{RESULTS AND DISCUSSION}

\section{The Implementation of Blended Learning Reading Section}

During the COVID 19 pandemic today, the use of blended learning is one the most recommended alternative. Due to the limited chance to meet face to face in the classroom and the lack of opportunity to conduct learning, as usual, the use of digital technology is the only choice to enable the learning process to continue. The following is a description of the implementation of blended learning for reading to write activity to create a process essay.

- Type: Process Essay

- Theme: Environmental Protection (Recycling, Reuse, Reduce)

- Learning objectives:

1. Identify the structure of the process essay

2. Analyzing the model text 
3. Identify the implicit and explicit information from the text

4. Identify the steps to make something

5. Identify the language used to make a process essay

6. Identify the vocabulary

7. Practice in using the vocabulary to make sentences that show a process

As usual, in the pre-activity, the lecturer delivered the learning objectives and checked the students' attendance list. The lecturer used Google application to check that all the students were present. The students' attendance was also recorded in Telegram Bot and from the screenshot of the Google application. For the warming up, the lecturer discussed the unused items around their home (plastics, cans, bottle, etc) and asked them whether those items can be reused and recycled. After the discussion, the students analyzed a model of process essay through Telegram application. The students had 5 minutes to scan the text and read silently and to find out the characteristics of a process essay in terms of its structure, vocabulary, and language.

After silent reading, there was a discussion about the reading text through the Telegram application. The discussion was about the specific information of the text, such as how the writer opens the essay, identifying the most important step, giving reasons why one step is more important than the other, mentioning the materials used, and stating how the writer writes the conclusion of the process essay. If the students had successfully answered the questions, the lecturer gave appreciation in the form of positive feedback (word/ phrases), and emoticons which show supports, for example very good, good job, perfect, well done, awesome, and so forth. Giving positive feedback is very important because it shows that students' participation and hard work are valued and appreciated by lecturers. Research has proven that providing positive feedback can increase the students' motivation and enthusiasm in learning Yingwen and Jian (2016). Positive feedback are also able to create more open and relaxed interactions between the lecturer and the students

The discussion also talked about other unused items found around their homes that can be recycled and reused for a different purpose. They were asked to name the vocabulary relevant to those items and the phrases used to indicate the process, such as first, second, third, next, then, finally. Then, the students made three sentences that indicated a process from the vocabulary mentioned earlier and posted for everyone to see in the Telegram application. Peers gave feedback in terms of the language and content. Based on the data, it can be concluded that the reading activity presented by the lecturer uses the skimming and scanning technique. Research in FL setting, especially in the Indonesian context, has shown that scanning and skimming techniques are beneficial to help comprehension Asmawati (2015), Basuki (2018), Fauzi (2018), Insiyah (2019). Skimming is to read quickly the reading material to get its general main idea, while scanning is to locate specific information related to the purpose of the reading activity Harmer
(2001).

The reading activity applied in this online classroom is silent reading. Hiebert et al. (2012) state that silent reading is more beneficial for the students if they are under an appropriate condition (tolerable difficulty level of a reading text). Furthermore, based on the research conducted by Liu and Wang (2015), for intermediate grade level, individual silent reading is more beneficial for the students.

\section{Writing Section}

The writing section is mostly done in an outside classroom schedule. The students sent their work to the lecturer through private telegram or WhatsApp connection to present their draft. But, before they wrote their draft, they shared their plan of what to write in their essay. The students proposed an idea of how to make something from an unused item. The plan would be developed into an essay.

- Type: Process Essay

- Theme: Environmental Protection (Recycling, Reuse, Reduce)

- Learning objectives:

1. Planning the essay

2. Drafting a Process essay

3. Revising the draft

4. Redrafting the essay

5. Publishing

After making the list proposal of the recycled items, the students made the initial draft for the process essay. This activity was conducted outside the classroom hour. It means that the students sent their draft in the form of MS Word format individually to the lecturer to be given feedback.

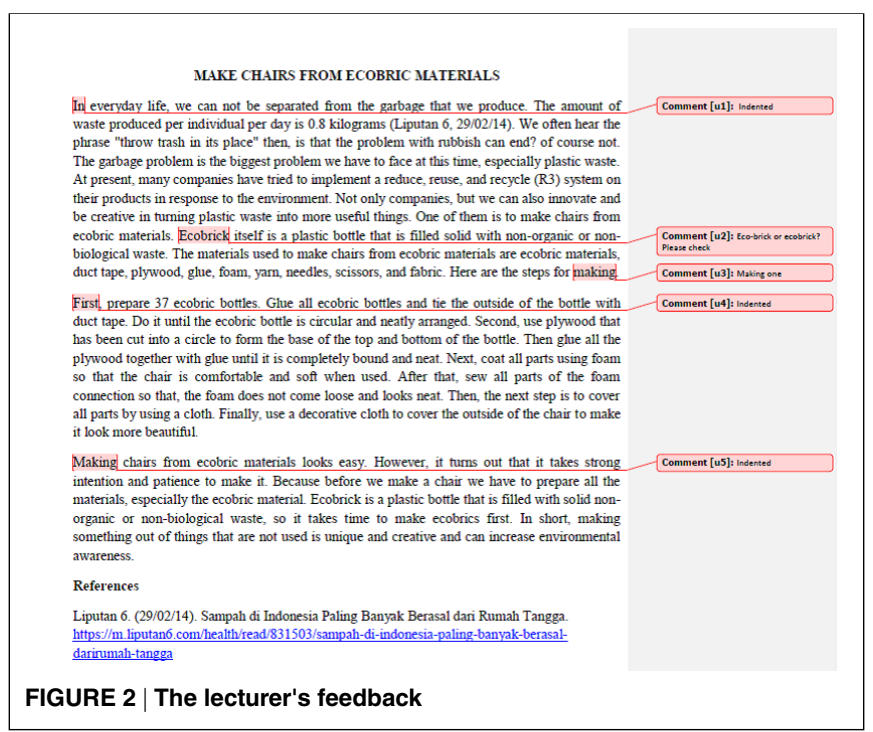

Some students revised the draft several times, depending on the writing problems. The lecturer assisted every student 


\section{Class A}

1. Phone holder from card board

2. Frame from box

3. pencil case from a tin

4. flower vase from newspaper

5. Make a tissue box from old newspapers

6. Make a pencil box from used cardboard

7. Frame ice cream sticks

8. Simple Chandelier card board

9. Make pencil case from bottle 10. Piggy Bank from unused bottle

11. Table from ecobric 12. Flower vase from unused bottle

13. Bros fabric

14. Frame from CD 15. Drawer from card board

16. Net Pot hydroponic from unused bottle

17. Frame from card board

18. Pencil case from unused bottle
Class B

1. Recycling Styrofoam for memo board

2. Tissue place from card board

3. Pencil case from unused tin

4. Flowers from plastic bags and unused papers

5. Bros from fabric

6. Doormat from unused fabric

7. Glasses from bottle and CD

8. Pencil case from card board

9. Eggs place souvenir from unused papers

10. Accessories from drinking glasses

11. Stationary box from CD and unused card board

12. shopping bag from unused fabric and unused plastic

13. Piggy bank from cigarette tin

14. Wall accessories from drinking glasses 15 . Waste bin from card board

16. Piggy bank from card board and checked their draft. Giving feedback to the students' writing is not an easy task because it needs time, energy, and commitment to read the students' composition. But, it is the teacher/lecturer's responsibility to devote some time to check, give comments, and give suggestions to the initial draft in the writing process Barreto (2011). Moreover, the students who follow the teacher/lecturer's feedback have more opportunities to have better writing quality Barreto (2011).
After being given feedback, the students revised their draft and sent back to the lecture for the final comment. For the students who were ready for publication, the lecturer asked the students to proofread their writing by utilizing the writing tools application provided on the internet. The students were asked to check their composition by using Grammarly online free application to deal with the language. To ensure originality, the lecturer asked the students to send the plagiarism report by using plagiarism check online for a free application, such as Smallseotools, Plagiarism, and Duplichecker.

After the students checked the language problems and originality, they published their work on their YouTube channel. Every work published on YouTube must include the hash tags of the students' institution/ faculty/ department. This is to give a sense of belonging and pride for the students' achievement.
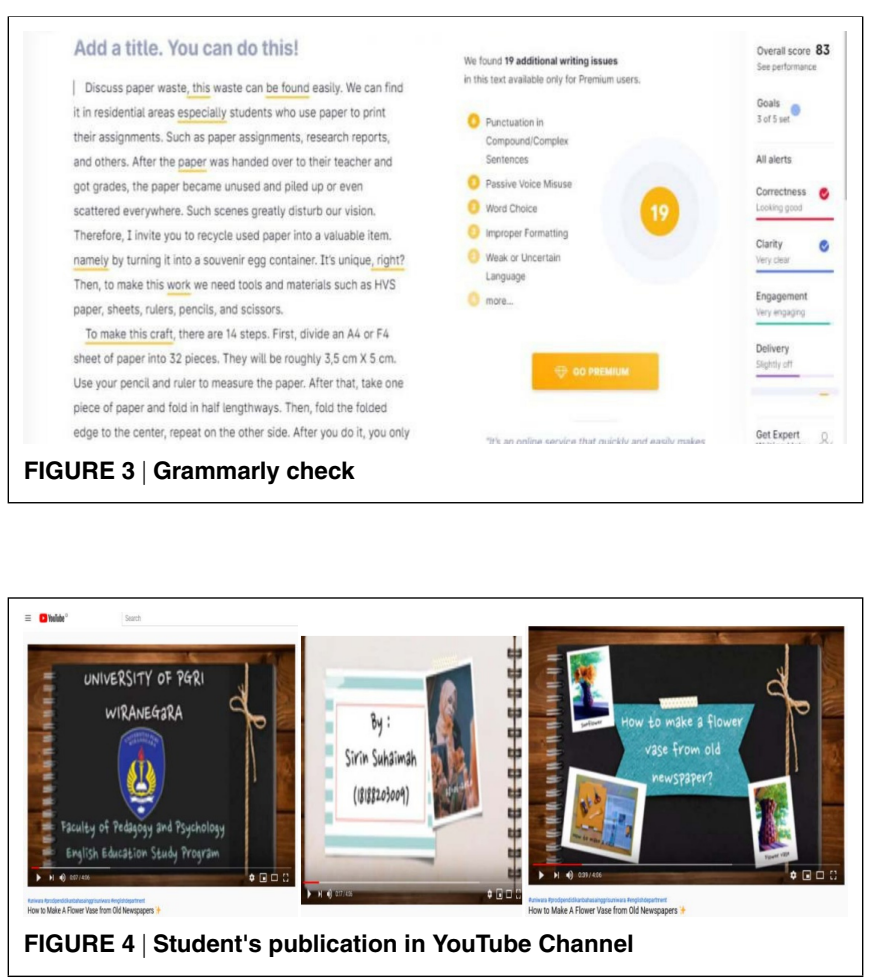

Each student was to press the like and subscribe button on another friend's YouTube channel. They were also to give opinions and responses in the comment sections. In general, the stages of learning to write by using the blended learning method can be seen in Table 1 .

The learning stages can change based on the students' needs. The COVID 19 pandemic has forced the lecturers to be adaptable to change, while at the same time to become innovative and creative in utilizing digital technology. Table 1 shows the learning stages which employ the writing as a process approach. Flower and Hayes (1981) and Hayes and Flower 
TABLE 3 | Teaching Scenario (Reading to write Activity for Process Essay)

\begin{tabular}{|c|c|c|}
\hline Stage & Activities & Applications \\
\hline \multirow{2}{*}{$\begin{array}{l}\text { Pre- } \\
\text { activity }\end{array}$} & 1. Descriptions of learning objectives & Face to face online \\
\hline & $\begin{array}{l}\text { 2. Making sure that all students are ready for } \\
\text { the class }\end{array}$ & $\begin{array}{l}\text { (Google meet) } \\
\text { Telegram }\end{array}$ \\
\hline \multirow[t]{7}{*}{$\begin{array}{l}\text { Whilst } \\
\text { Activity }\end{array}$} & $\begin{array}{l}\text { 1. Discussing the topic for background knowledge } \\
\text { knowledge }\end{array}$ & 1. Google Meet \\
\hline & 2. Analyzing the model text & 2. Telegram (silent reading) \\
\hline & $\begin{array}{l}\text { 3. Practicing the vocabulary and phrases } \\
\text { used for process essay }\end{array}$ & $\begin{array}{l}\text { 3. Telegram } \\
\text { 4. Telegram and Whatsapp }\end{array}$ \\
\hline & 4. Planning the essay & Group \\
\hline & $\begin{array}{l}\text { 5. Making a draft based on the topic of } \\
\text { interest individually }\end{array}$ & $\begin{array}{l}\text { 5. Telegram and Whatsapp } \\
\text { Group }\end{array}$ \\
\hline & $\begin{array}{l}\text { 6. Revising the draft after being given } \\
\text { feedback }\end{array}$ & $\begin{array}{l}\text { 6. Telegram and Whatsapp } \\
\text { Group }\end{array}$ \\
\hline & 7. Redrafting & $\begin{array}{l}\text { 7. Telegram and Whatsapp } \\
\text { Group }\end{array}$ \\
\hline Post & Publishing & Personal You Tube channel \\
\hline Activity & & \\
\hline
\end{tabular}

(1980) state that there are three main cognitive processes in writing, namely planning (generating ideas, organizing, and goal-setting), translating (composing), and reviewing (checking and correcting). Similarly, Sharp (2016) states that every piece of writing product undergoes several different processes, before it finally comes to the final draft and is ready for publication. The reading to write activity presented by the lecturer employs the writing as a process approach. This can be seen from the students' activity in producing the final draft. They followed several steps before their composition is finally submitted or published.

\section{The Students' Opinion}

The researchers interviewed the students to find out their feelings and opinion of having an online class. A month after the 'learn from home' and 'work from home' orders were announced by the government, the researchers interviewed the students.

Researcher: How would you like about having a class like this?

I don't like it. Full of surprises. I mean we need some explanation about the topic of the unit before we get into the questions. In this situation, we need something real, something that can open our minds, because the online class has many distractions.
A month later, the same student was interviewed by the researcher. He has a different opinion about having an online class.

The researcher: How would you like to have an online class for writing? Is it better to have it in the classroom (face to face) or at home (online)?

I prefer to do it at home. I can listen to music.

(Ad/2018A/Ch)

The same case also happens to his friends. They share the same opinions and attitudes after a few months of remote learning.

By and by, I enjoy online class rather than offline class

(Af/2018A/Ch)

I get used to it

(Els/ 2018B/Ch)

I think I understand the material well even though we don't have the face to face meeting.

(Silf/2018A/Ch)

The students also said that the assignment given by the lecturer made the students learned not only about the materials, but also digital technology.

Now, I can edit a video. 
I learn how to edit a video, even though the result is not like a professional one

$(E m / 2018 B / c h)$

Finally, my YouTube Channel has some content

\section{(Naf/201B/Ch)}

However, there were some problems during the process of the remote learning. The problems were the signal and the quota.

\section{I understand the lesson, even though signal} becomes my problem sometimes

(Put/2018A/ch)

But in my region, the signal is really hard

(Els/ 2018A/ch)

In my region, I have a problem with the signal

(suc/2018B/ch)

Overall, students feel positive about the use of online learning. The data shows that they learned a lot. Even though some of them feel reluctant and uneasy in the beginning. Yet, they get used to it, and perhaps even, enjoy it.

The positive perception in this study is similar to a study conducted by Mahalli et al. (2020). Their finding shows that the students who experienced blended learning experienced satisfaction felt confident with the use of technology, and were attentive during learning. Research conducted by Rodriguez et al. (2008) has shown that students who have hybrid learning experience perceived comfort as having a strong motive in learning and having a good quality of online course. As stated by Dahlia et al. (2020) and Salas-Rueda (2020), blended learning is one of the possible alternatives to having a better quality teaching and learning process in the 21 st century, and should be part of any educational program in the future Altay and Altay (2019).

The signal and quota are the problems faced by the students in Indonesia. Not many Indonesian students live in an area where the internet connection is fast and stable. Arizona et al. (2020) state that the teaching problems faced during the pandemic are the quota and the lack of practical knowledge from the educators and students in terms of how to make the best use of the technology for the teaching and learning process. Thus, to solve this problem, they suggest that teachers should get themselves acquainted with the provided free online application for teaching and learning. The solution of the quota and internet connection problems requires collaboration by many parties, among them, are the family, the institution, the service provider, and the government.

\section{CONCLUSION}

The pandemic of COVID 19 has shaped the way the teachers/lecturers teach nowadays. The stay home orders forced the educators to shift from the conventional face to face meeting to technology-based instruction. Based on the data, the researchers draw a conclusion that the teaching and learning process in the blended learning setting still follows the typical stages of teaching, namely the pre-activity, whilst activity, and post-activity. Each of these stages varies according to the skill being taught. The reading activity reported in this study employed the silent reading activity, and skimming and scanning technique, while the writing activity used the process approach, namely planning, drafting, revising, and publishing. The technologies used in the blended learning model are Telegram, WhatsApp, Google Meet, YouTube, Grammarly, and Plagiarism Checker online application. Even though the students felt discouraged in the beginning, they felt positive about the hybrid model. They had more knowledge, not only in terms of the materials and language skills but also in the operation of the technology.

Blended learning gives three important messages. Firstly, it is impossible to memorize all of the available knowledge. So, education is no longer about how many facts can be memorized and not about how perfect the learners perform in a test. But education is more about how to apply the knowledge in real life and how to get valid and reliable information. Secondly, blended learning shows that the class is not the only place to learn. Learning is an endless process that can take place everywhere, anytime, and with anyone. Knowledge is not a fixed and rigid fact, but knowledge is one thing that is always changing, evolving, and adapting. And thirdly, a blended learning model implies that the teacher does not have all answers to all problems. In this learning model, the teacher acts as a guide, motivator, and moderator and is no longer the only source of information for the students. Every teacher dream that their students will continue learning even if they have finished their formal education. In sum, blended learning gives opportunities for the students to keep on searching for knowledge and improve their self-quality, and be ready to plunge into real life.

\section{ACKNOWLEDGEMENTS}

This research is fully supported by the Indonesian Directorate of Research and Community Engagement (DRPM) of Higher Education for funding in 2020. 


\section{REFERENCES}

Allen, I. E., Seaman, J., and Garrett, R. (2007). Blending in: The Extent and Promise of Blended Education in the United States. The Sloan Consortium, 1-29.

Altay, I. F. and Altay, A. (2019). A Review of Studies on Blended Learning in EFL Environment. International Journal of Curriculum and Instruction 11, 125-140.

Arizona, K., Abidin, Z., and Rumansyah, R. (2020). Pembelajaran Online Berbasis Proyek Salah Satu Solusi Kegiatan Belajar Mengajar Di Tengah Pandemi Covid19. Jurnal Ilmiah Profesi Pendidikan 5, 64-70.

Asmawati, A. (2015). The Effectiveness Of Skimming - Scanning Strategy in Improving Student Reading Comprehension At The Second Grade of SMK Darussalam Makassar. ETERNAL (English, Teaching, Learning and Research Journal), I, 6983

Barreto, A. M. R. (2011). Improving Writing through Stages. Improving Writing through Stages. How 18, 11-23.

Basuki, S. (2018). Applying Scanning And Skimming Skills to Understand Life Skills Reading. Journal of English Language and Literature (JELL) 3, 129-142.

Creswell, J. W. (2012). Educational Research: Planning, Conducting, and Evaluating Quantitative and Qualitative Research. In Educational Research 4.

Dahlia, A., Musty, B., and Rahman, A. A. (2020). The Effectiveness of Blended Learning in Improving Students. English Journal Literacy Utama 4, 152-157. doi: 10.33197/ejlutama.vol4.iss 1.2020.380.

Fauzi, I. (2018). The Effectiveness of Skimming and Scanning Strategies in Improving Comprehension and Reading Speed Rates to Students of English Study Programme. Register Journal 11.

Flower, L. and Hayes, J. R. (1981). A Cognitive Process Theory of Writing. doi: 10.2307/356600. https://dx.doi.org/10.2307/356600.

Graham, C. R. (2006). Book Review : The Practice of English Language Teaching. Handbook of Blended Learning Global Perspectives Local Designs 32, 135-136.

Harmer, J. (2001). Book Review : The Practice of English Language Teaching. RELC Journal 32, 135-136. doi: 10.1177/003368820103200109.

Hayati, N. and Wijaya, M. (2018). Pengelolaan Pembelajaran melalui Blanded Learning dalam Meningkatkan Receptive Skill Peserta Didik di Pondok Pesantren. PALAPA 6, 1-18. doi: 10.36088/palapa.v6i2.64.

Hayes, J. R. and Flower, L. S. (1980). Identifying the Organisation of the Writing Process. Cognitive Processes in Writing, 3-30.

Hiebert, E. H., Samuels, S. J., and Rasinski, T. (2012). Comprehension-Based Silent Reading Rates: What Do We Know? What Do We Need to Know? Literacy Research and Instruction 51, 110-124. doi: 10.1080/19388071.2010.531887.

Idris, H. (2018). Pembelajaran Model Blended Learning. Jurnal Ilmiah Iqra, 5-5.

Insiyah, I. (2019). STRATEGI SKIMMING DALAM MENINGKATKAN EFEKTIVITAS BACA SISWA PADA KELAS XI SMK NURUL JADID PAITON PROBOLINGGO. doi: 10.33650/edureligia.v2i1.753. https://dx.doi.org/10. 33650/edureligia.v2i1.753.

Liu, S. and Wang, J. (2015). Reading Cooperatively or Independently? Study on ELL Student Reading Development. Reading Cooperatively or Independently? Study on ELL Student Reading Development. Reading Matrix: An International Online Journal 15, 102-120.

Mabuan, R. A. and Ebron, G. P. (2017). A Blended Learning Approach to Teaching Writing: Using E-mail in the ESL Classroom. The Asian EFL Journal 100, 80-103.

Mahalli, N., Mujiyanto, J., Yuliasri, J., and I (2020). Students' Perception Of Blended Learning Implementation in EFL Learning. International Journal of Innovation, Creativity and Change 11, 161-172.

Mccall (2017). Using Microblogs on Facebook to Develop Students' Academic Reading and Writing Skills. Using Microblogs on Facebook to Develop Students' Academic Reading and Writing Skills 12, 123-162.

Miles, M. A. and Huberman, M. B. (1994). In Qualitative Data Analysis: An Expanded Sourcebook (Miles and Huberman), 50-72.

Osguthorpe, R. and Graham, C. (2003). Blended Learning Systems: Definitions and Directions. Quarterly Review of Distance Education 4, 227-234.

Purnawarman, P., Susilawati, S., and Sundayana, W. (2016). The use of Edmodo in teaching writing in a blended learning setting. Indonesian Journal of Applied Linguistics 5, 242-242. doi: 10.17509/ijal.v5i2.1348.

Rahman, A. and M, A. (2018). English Writing Performance Using Blended Learning In Tvet Education. Literature, and Language Teaching 2, 28-36.

Rodriguez, M. C., Ooms, A., and Montañez, M. (2008). Students' Perceptions of Online-Learning Quality Given Comfort, Motivation, Satisfaction, and Experience. Journal of Interactive Online Learning 7, 105-125.

Salas-Rueda, R. A. (2020). Perception of Students on Blended Learning Considering Data Science and Machine Learning. Perception of Students on Blended Learning Considering Data Science and Machine Learning. Campus Virtuales 9, 125-135.

Sharp, L. A. (2016). Acts of writing: A Compilation of Six Models that Define the Processes of Writing. International Journal of Instruction 9, 77-90.

Tandoh, K., Flis, N., and Blankson, J. (2013). Blended Learning: History, Implementation, Benefits, and Challenges in Higher Education. Practical Applications and Experiences in K-20 Blended Learning Environments, 18-27.

Yingwen, S. and Jian, S. (2016). A Study of Appreciation Resources In Teacher Feedback In The Chinese College EFL Context. Learning in and beyond the Classroom: Ubiquity in Foreign Language Education. The Seventh CLS International Conference CLaSIC, 443-459.

Conflict of Interest Statement: The authors declare that the research was conducted in the absence of any commercial or financial relationships that could be construed as a potential conflict of interest.

Copyright (C) 2021 Setyowati, Sukmawan and El-Sulukkiyah. This is an open-access article distributed under the terms of the Creative Commons Attribution License (CC $B Y$ ). The use, distribution or reproduction in other forums is permitted, provided the original author(s) and the copyright owner(s) are credited and that the original publication in this journal is cited, in accordance with accepted academic practice. No use, distribution or reproduction is permitted which does not comply with these terms. 